\title{
Mean Blood Flow Velocity
}

National Cancer Institute

\section{Source}

National Cancer Institute. Mean Blood Flow Velocity. NCI Thesaurus. Code C127570.

The measurement of the average rate of blood flow across an area or tissue. 